\title{
Criação de produtos de informação: a experiência do Sebrae/MT
}

\section{Vanda Ferreira dos Santos}

\section{Resumo}

Relato de experiência do Centro de Documentação e Informação do Sebrae/MT referente à criação de produtos informacionais. Aborda os desafios e o novo conceito que está permeando os centros de documentação. Apresenta o processo de criação de produtos informacionais, desde a sua concepção até a sua execução, com depoimentos de clientes que já estão utilizando o produto.

\section{Palavras-chave}

Produto de informação; Serviço de informação.

\section{INTRODUÇÃO}

Nos tempos atuais, caracterizados por novas necessidades, os dirigentes das corporações estão repensando os modelos de gestão, para que as suas diversas unidades justifiquem-se financeiramente. Os sistemas de informação, sejam eles bibliotecas, centros de documentação, centros de informação, entre outros, também devem buscar ser um centro de resultados.

O Centro de Documentação e Informação do Sebrae/MT foi criado em 1976 para dar suporte técnico às realizações do Agente. Evoluindo deste conceito, o CDI está se tornando uma unidade de negócios e, como tal, tem buscado a criação e o desenvolvimento de produtos e serviços de informação capazes de atender aos interesses específicos das empresas, dos empresários e dos profissionais em geral.

A experiência de ter criado produtos de informação com um enfoque inovador e criativo, voltado para a formação de pessoas, tem mudado o conceito do CDI no Sebrae/MT, tanto para o pessoal interno da empresa, quanto para seus dirigentes, que estão percebendo o Centro de Documentação como uma unidade de geração de novos produtos e serviços.

\section{SERVIÇO DE INFORMAÇÃO SEBRAE}

O Serviço de Informação Sebrae (SIS) foi idealizado em 1997, com a proposta de disseminar informações para as pessoas sem tempo para acessar veículos como jornais, revistas, informativos etc. Ele está estruturado em duas formas distintas, visando a atingir públicos-alvo específicos, com produtos dirigidos: um é voltado para os funcionários da em- presa, o Informural, disponibilizado em seu próprio local de trabalho; os outros são voltados para executivos, profissionais liberais e outros. São eles o Alerta Empresarial e o Informação Pontual.

A idéia de criação do Informural surgiu da experiência interna de prestação desse serviço para os técnicos e também de um benchmarking de um mural mantido pela Assessoria de Comunicação, com informações, dicas, utilidade pública etc., utilizado para fomentar a comunicação interna. Agrupamos todos os resultados obtidos e otimizamos alguns processos para idealizar os novos produtos.

Sua formatação teve o envolvimento de vários profissionais de áreas afins: jornalistas, programadores visuais, literatos, administradores, economistas e contadores. Houve também a importante participação da assessoria de marketing e de um consultor especializado na área financeira, que fizeram a análise de viabilidade dos produtos do ponto de vista financeiro e mercadológico.

Em um mês de lançamento do Informural, conseguiu-se superar as metas de vendas previstas para os três primeiros meses.

O Alerta Empresarial e o Informação Pontualtêm sua previsão de lançamento para o mês de abril, entretanto, nas visitas realizadas para vendas do Informural, já estão sendo apresentados os novos produtos a serem lançados e tem havido ótima aceitação da idéia. 


\section{CONCEITO E NATUREZA DOS PRODUTOS}

\section{Informural}

Serviço de seleção e fornecimento de artigos veiculados nos meios de comunicação impressos (jornais, revistas, boletins, informativos etc.) e eletrônicos (publicações via Internet) sobre recursos humanos, comportamento, motivação, vendas, marketing, atendimento, informática, qualidade, tendências, cultura, saúde, liderança, cases de sucesso (experiências de outras empresas) etc.

Periodicidade: quinzenal

Formato: quadro mural

\section{Alerta Empresarial (clipping)}

Produto informacional de seleção, coleta e disponibilização de matérias veiculadas nos meios de comunicação impressos e eletrônicos sobre gestão de empresas, abrangendo as áreas de vendas, marketing, marketing pessoal, informática, recursos humanos, finanças, administração etc.

Periodicidade: mensal

Formato: ofício A4

\section{Distribuição: Correios}

\section{Informação Pontual}

Produto informacional de seleção de matérias veiculadas nos meios de comunicação impressos e eletrônicos sobre os mais diversos assuntos da área empresarial, tais como tendências do mercado, negócios, gestão etc., e que tenham principalmente caráter de urgência.

O fornecimento dos artigos será por meio de folhas avulsas, no máximo duas.

Periodicidade: semanal

Formato: ofício A4

Distribuição: Correios ou fax (escolha do cliente)

\section{TABELA DE APURAÇÃO}

\section{CUSTO DIRETO}

1.1 Pessoal (custos calculados em horas técnicas. Para conhecermos o custo unitário da hora de um técnico ou estagiário, apuramos os valores mensais de salários + encargos sociais + benefícios + outros (se houver) e dividimos pelo número de horas técnicas trabalhadas no mês);

1.2 Correspondência (despesas com remessas dos produtos, por meio dos Correios e Telegráfos);

1.3 Serviços de terceiros (total de custos com os itens relacionados abaixo):

1.3.1 Gráfica (despesas com serviços de impressão);

1.3.2 Programação visual (despesas com editoração e arte dos produtos);

1.3.3 Reprografia (despesas com fotocópias);

1.3.4 Outros (custos dos demais serviços não enquadrados nos itens anteriores);

\section{COMERCIALIZAÇÃO}

O SIS será comercializado mediante assinaturas semestrais e anuais, com uma política de preço diferenciada para micro e pequena empresa, na venda do Informural. O Alerta Empresariale o Informação Pontual são destinados às pessoas físicas, com preço único.

\section{ESTRUTURA}

\section{Pessoal}

Um técnico e um assistente-técnico de nível superior (bibliotecário e administrador) para seleção dos artigos.

Um assistente-técnico de nível superior (economista) para controle financeiro e contato com fornecedores.

Contamos ainda com a colaboração de duas estagiárias de nível superior, com formação em ciências contábeis e administração. A equipe de vendas funciona em regime de rodízio com profissionais de outras equipes, das mais diversas formações.

\section{CUSTO INDIRETO}

2.1 Taxa de administração (compreende os itens abaixo discriminados. Seu cálculo é feito com base em um percentual de $30 \%$ do custo total - margem estabelecida pelo Sebrae/MT):

2.1.1 Pessoal de apoio técnico/administrativo (compreende rateio do pessoal de apoio);

2.1.2 Material de consumo (despesas com todo material envolvido na produção dos produtos);

2.1.3 Comunicação (despesas com telefone, fax, etc.):

2.1.4 Depreciação (depreciação de equipamentos e mobiliário, geralmente de cinco anos);

2.1.5 Água, luz, força etc.

\section{CUSTOS}

A apuração dos custos dos produtos informacionais foi feita baseada no levantamento dos gastos diretos e indiretos envolvidos no processo.

\section{CONCLUSÃO}

A realização destes trabalhos tem nos dado uma satisfação muito grande, não apenas em nível pessoal, mas também, principalmente, profissional. Ver um produto nascer, ou melhor, concebê-lo, acompanhar o processo de gestação, conviver com as dúvidas, propiciou-nos grande experiência e tem proporcionado grande satisfação constatar que o produto tem atendido às necessidades do empresariado, tem e está cumprindo sua principal missão - a de informar.

Esperamos, com este artigo, apresentar uma nova perspectiva e estimular a criação de produtos na área de informação, ou seja, vislumbrar novos caminhos e desafios para os colegas de profissão. 


\section{Depoimentos}

"Os textos simples e objetivos são facilmente lidos pelos colaboradores e isto tem estimulado uma mudança de comportamento. Podemos perceber uma motivação maior do pessoal, tanto para treinamentos, quanto para o desenvolvimento pessoal e melhorias internas."

Célio Fernandes ( Proprietário da Biológica - Farmácia de Manipulação)

"Com a assinatura do Informural, aumentaram minhas vendas, pois os clientes ficam lendo os artigos e lanchando".

\section{Aparecido Vitorino (Proprietário da Padaria Tropical)}

"Informural - está de parabéns o Sebrae/MT por mais esse serviço. A nossa empresa está tirando bastante proveito e julgamos a iniciativa altamente positiva".

Flozino Rocha ( Proprietário -

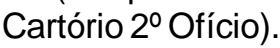

\section{REFERÊNCIAS BIBLIOGRÁFICAS}

1. Funcionamiento de un servicio de información comercial: manual para los países en desarrollo. Ginebra: Centro de Comercio Internacional UNCTAD-GATT, 1975. $169 \mathrm{p}$.

2. Gestão de unidades de informação: manual. Curitiba: Tecpar; Brasília: IBICT, 1997. 257 p.

Artigo aceito para publicação em 15-5-98.

\section{Agradecimentos}

Agradeço aos colegas da área de informação do Sebrae/MT, que tanto se empenharam em tornar realidade 0 projeto dos produtos informacionais, em especial a Geni Gomes, Marisbeth Gonçalves, Sandra Regina, Sandra Paula, Sandra Simon e Welinton Pasdiora, bem como a assessora de Planejamento, Eliane Ribeiro Chaves, a assessora de Marketing, Marta Torezam, a responsável pela Editoração, Débora Lapinski, e o diretor-superintendente, José GuiIherme Barbosa Ribeiro, incentivadores dos nossos sonhos.

\section{Vanda Ferreira dos Santos}

Bibliotecária responsável pela Unidade de Produção da Informação e Centro de Documentação e Informação do Sebrae/MT. 